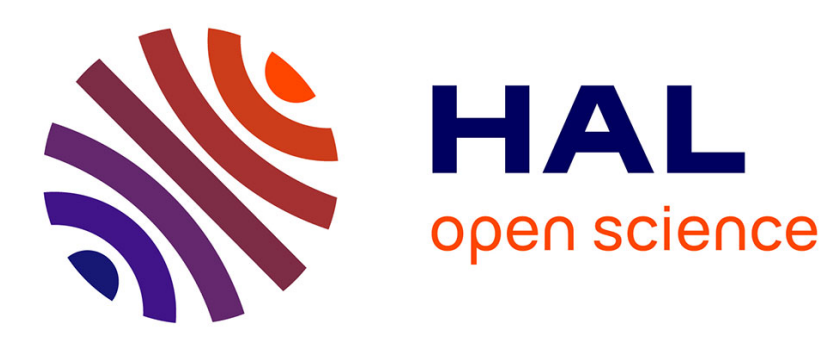

\title{
No evidence of a new magmatic gas contribution to the Solfatara volcanic gases, during the Bradyseismic crisis at Campi Flegrei (Italy). \\ D. Tedesco, R. Pece, J.C. Sabroux
}

\section{- To cite this version:}

D. Tedesco, R. Pece, J.C. Sabroux. No evidence of a new magmatic gas contribution to the Solfatara volcanic gases, during the Bradyseismic crisis at Campi Flegrei (Italy).. Geophysical Research Letters, 1988, 15 (12), pp.1441-1444. 10.1029/GL015i012p01441 . hal-03551313

\section{HAL Id: hal-03551313 \\ https://hal.science/hal-03551313}

Submitted on 1 Feb 2022

HAL is a multi-disciplinary open access archive for the deposit and dissemination of scientific research documents, whether they are published or not. The documents may come from teaching and research institutions in France or abroad, or from public or private research centers.
L'archive ouverte pluridisciplinaire HAL, est destinée au dépôt et à la diffusion de documents scientifiques de niveau recherche, publiés ou non, émanant des établissements d'enseignement et de recherche français ou étrangers, des laboratoires publics ou privés. 


\author{
NO EVIDENCE OF A NEW MAGMATIC GAS CONTRIBUTION TO THE SOLFATARA \\ VOLCANIC GASES, DURING THE BRADYSEISMIC CRISIS \\ AT CAMPI FLEGREI (ITALY). \\ ${ }^{1,2}$ D. Tedesco ${ }^{2,3}$ R. Pece and ${ }^{1}$ J.C. Sabroux
}

\begin{abstract}
A volcano-tectonic crisis with strong seismic activity and rapid uplift started in 1982, and continued until its abrupt disappearance at the beginning of 1985, at Campi Flegrei caldera (Southem Italy). The chemical composition of the fumarolic fluids has been recorded during the last five years and, from geochemical and thermodynamical considerations, it has been deduced that the shallow reservoir feeding the fumaroles remained chemically isolated, at least with respect to major magmatic components, from the magma chamber inferred to be located at depth.
\end{abstract}

\section{Introduction}

A volcano-tectonic crisis, with a large uplift (more than $1.80 \mathrm{~m}$. in about 2 years) and intense seismic activity (several quakes with $M>3.5$ ), began in the middle of 1982 at the Campi Flegrei caldera (Southern Italy, Figure 1). The maximum uplift and most of the hypocenters were centered under the town of Pozzuoli (central part of the caldera) from where about 40,000 persons were evacuated [Barberi et al., 1984; Berrino et al., 1984]. The uplift and the seismic activity vanished at the beginning of 1985 [Bernino et al., 1986; Lirer et al., 1987]. Since October 1983, a few months before the climax of the bradyseismic crisis, we took and analyzed more than one hundred gas samples from fumaroles in the Solfatara crater, (the most active fumarolic area on land in the Campi Flegrei). Some interesting temporal variations in the composition of gas species were observed and thermodynamics was used to:

1) determine the equilibrium temperature of gas at depth, 2) follow, if present, a thermodynamical evolution in the hydrothermal reservoir, 3 ) detect possible new or renewed magmatic activity in the magma chamber.

\section{Experimental}

Sampling of the fumarolic gases was carried out using evacuated flasks filled with a $4 \mathrm{~N} \mathrm{NaOH}$ solution (Giggenbach, 1975). To avoid atmospheric contamination and to prevent gas cooling, dewar quartz tubes were used to introduce the gases from the fumarolic vent to the flask. Analyses were performed by gas-chromatography: $\mathrm{He}, \mathrm{H}_{2}$, $\mathrm{O}_{2}+\mathrm{Ar}, \mathrm{N}_{2}$ and $\mathrm{CH}_{4}$ have been measured with a thermal conductivity detector and $\mathrm{CO}$ with a specific analytical method using a methaniser before a flame ionization detector, which allowed an overall sensitivity of better than $1 \mathrm{ppm}$ of carbon monoxide. $\mathrm{CO}_{2}$, and $\mathrm{H}_{2} \mathrm{~S}$ were analysed using electrochemical methods: $\mathrm{CO}_{2}$ by titration (pH-meter), and $\mathrm{H}_{2} \mathrm{~S}$ as sulfide $\left(\mathrm{S}^{--}\right)$through titration by $\mathrm{Pb}^{++}$(ion-

\footnotetext{
${ }^{1}$ Centre des Faibles Radioactivités, Laboratoire mixte CNRS-CEA BP 1, 91198 Gif-sur-Yvette (France)

2Osservatorio Vesuviano Napoli (Italy)

3Università di Napoli Dipartimento di Geofisica e

Vulcanologia Napoli, Italy
}

Copyright 1988 by the American Geophysical Union.

Paper number 88GL03446.

0094-8276/88/88GL-03446\$03.00 specific electrode). The water content of the samples was obtained by difference in total weight before and after the sampling [Tedesco and Sabroux, 1987].

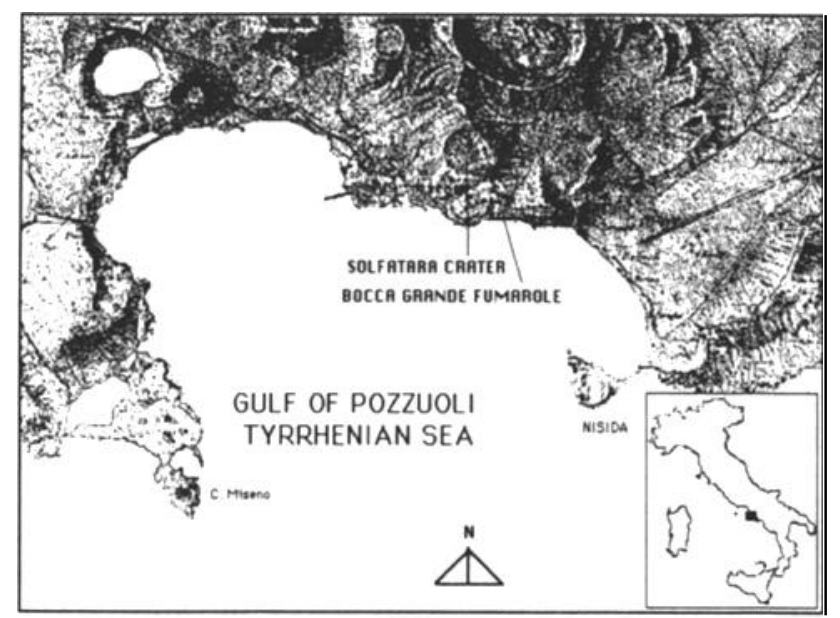

Figure 1. Campi Flegrei caldera map, where the Solfatara crater and the Bocca Grande fumarole are located.

\section{Discussion of results}

The geophysical network of the Osservatorio Vesuviano continuously monitored ground deformation and seismic activity as shown in Fig. 2 (expressed as strain release). While at the beginning of our sampling which started in October 1983 and continued until February 1984, we did not detect any significant variation in concentration, starting in March 1984 the concentration of all the reduced species decreased in the dry gases: hydrogen sulfide dropped from 2.0 to $0.6 \%$ (minimum value $0.5 \%$ ), hydrogen from 0.20 to $0.13 \%$ (minimum value 0.11 ), methane from 250 to 180 ppm (minimum value $50 \mathrm{ppm}$ ), and the sulfur/carbon ratio changed from $2,20 * 10^{-2}$ to $0.65 * 10^{-2}$ (Fig. 3). Water vapor started to decrease some months later (January 1985) from 91.0 to $83.0 \%$ (minimum value $78.5 \%$ ) (Figure 3).

The fluids of the Solfatara crater which have been sampled since 1923 [Salvatore, 1923, in Le Guem, 1973], through 1970 [Dall'Áglio et al., 1972; Le Guern, 1973] until today [Cioni et al., 1983; Cioni et al., 1984; Martini et al., 1986; Tedesco and Sabroux, 1987; Tedesco, 1987] have always been known for their outstanding chemical stability (Table 1).

\begin{tabular}{lllllll}
\multicolumn{7}{c}{ Tablel } \\
\hline Salvatore & (1923) & 99.2 & 0.5 & 0.26 & 0.1 & 0.01 \\
Rittmann & (1934) & 99.4 & 0.5 & 0.23 & 0.1 & 0.01 \\
Sborgi & $(1939)$ & 98.9 & 0.9 & 0.26 & 0.1 & 0.01 \\
Dall'Aglio (1972) & 99.2 & $0.4-0.6$ & 0.20 & n.d. & n.d. \\
Le Guern & (1973) & 99.0 & 0.4 & 0.20 & n.d. & n.d. \\
\hline
\end{tabular}



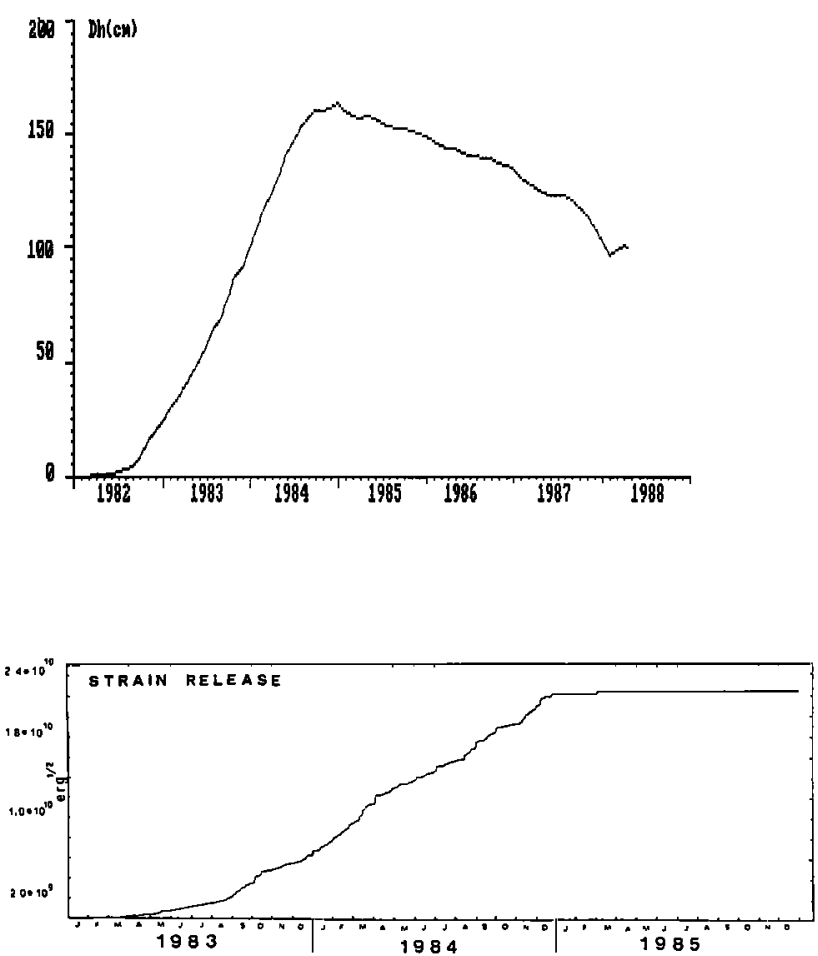

Figure 2. Vertical ground deformation measured at Pozzuoli harbor by tide gauge and accumulated strain release related to the seismicity in the Campi Flegrei.

We consider a normal concentration level for the Solfatara fluids to be what other authors have found since 1923 until the recent past (Table 1), before the variations started in 1980, two years before the crisis when the thermodynamical conditions of the reservoir(s) were stable. Actual concentrations (1988) are considered in the normal range of values.

The concentrations of chemical species that we find today, after the variations due to the bradyseismic crisis are very close to previous data monitored in the past. Fluid concentrations (gas) at the moment appear to be returning to the same equilibrium as before the crisis. In fact we believe that the thermodynamical conditions in the hydrothermal system feeding the fumaroles of the Solfatara crater are now restored. For this reason, the chemical variations recorded during our sampling can be due only to a lack of thermal flow (water vapour) coming from deeper to shallower acquifers, the opposite to what occurred before the crisis. Seasonal variations are more than variations due to the volcanic system itself and some regularly affect gas phase species eg. $\mathrm{H}_{2} \mathrm{~S}, \mathrm{H}_{2}$ and $\mathrm{CH}_{4}$. In fact we usually detect a concentration maximum of these species in October with a minimum (reflected also on the calculated equilibrium temperature) occurring during summer time. This is conspicuous in 1984 and 1985, and more difficult to detect in 1986, maybe because of the chemical changes related to the seismic swarm of April 1987 (Tedesco et al., 1988) Thus, obvious changes in the geochemistry of the Solfatara fumaroles, were associated with the recent volcano-tectonic crisis in the Campi Flegrei. Moreover, these changes seem to have preceeded the variations in the geophysical parameters, both at the beginning and at the end of the crisis. In particular, a significant increase in the concentration of some species $\left(\mathrm{H}_{2} \mathrm{O}, \mathrm{H}_{2} \mathrm{~S}, \mathrm{CH}_{4}\right)$ in Solfatara gases seems to have preceded the bradyseismic activity, and this has been detected by some authors since 1980 [Cioni et al., 1983; Cioni et al.,
1984 and Martini, 1986]. Our sampling which started in October 1983 when the uplift and seismic activity at Campi Flegrei were still continuing, cannot confirm the forerunning character of the geochemical parameters.

Two main different hypotheses may be considered to try to explain these variations: a) contribution of hot and deep gases from the magma reservoir at depth; b) changes in the thermodynamic regime of the geothermal system due to the tectonic activity. For this purpose we have studied two different reactions within the gas phase: the conversion reaction:

$$
\mathrm{CO}+\mathrm{H}_{2} \mathrm{O} \leftrightarrow \mathrm{H}_{2}+\mathrm{CO}_{2} \quad 1
$$

the equilibrium of which depends only on temperature; and the Fischer-Tropsch reaction:

$$
\mathrm{CH}_{4}+2 \mathrm{H}_{2} \mathrm{O}<->4 \mathrm{H}_{2}+\mathrm{CO}_{2}
$$

which depends on both temperature and pressure. In both cases, we assume that chemical equilibrium between the gas species was attained when they separated from the reservoir and quenched during the ascent to the surface. This allows us to calculate an equilibrium temperature from the conversion reaction based on thermodynamical data to be [Barin et al., 1977] $250 \pm 20^{\circ} \mathrm{C}$, until 1985 and a decrease to $220 \pm 20^{\circ} \mathrm{C}$ until today (Figure, 3). These two temperatures of $250^{\circ} \mathrm{C}$ and $220^{\circ} \mathrm{C}$ correspond to a saturated vapour pressure of 39.3 and $23.2 \mathrm{~atm}$ respectively which are close to the temperature and pressure of maximum enthalpy of saturated steam $\left(235^{\circ} \mathrm{C}\right.$ and 31,24 atm) [Irvine and Hartnett, 1976]. These values suggest that equilibrium is attained in a water

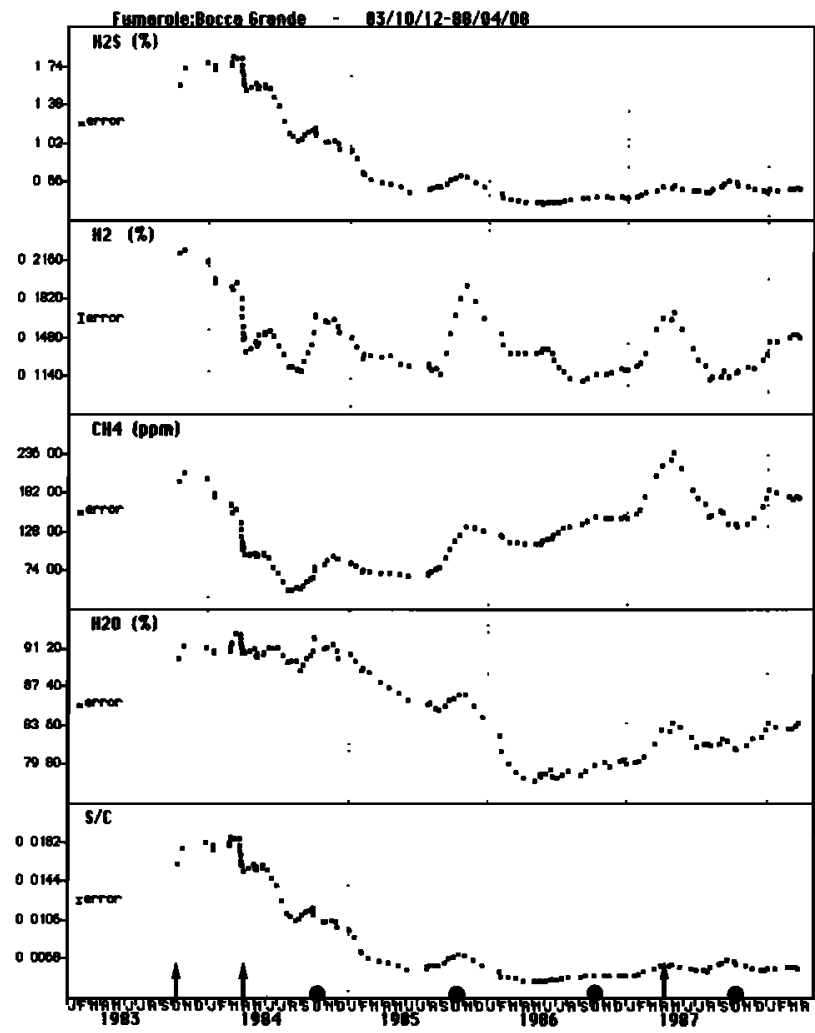

Figure 3. All species show the same trend, a rapid decrease from February 1984, except water vapour started on December 1984. Seasonal oscillations (circles) always start between September- November each year. Arrows indicate the main seismic swarms occurring during this period. 


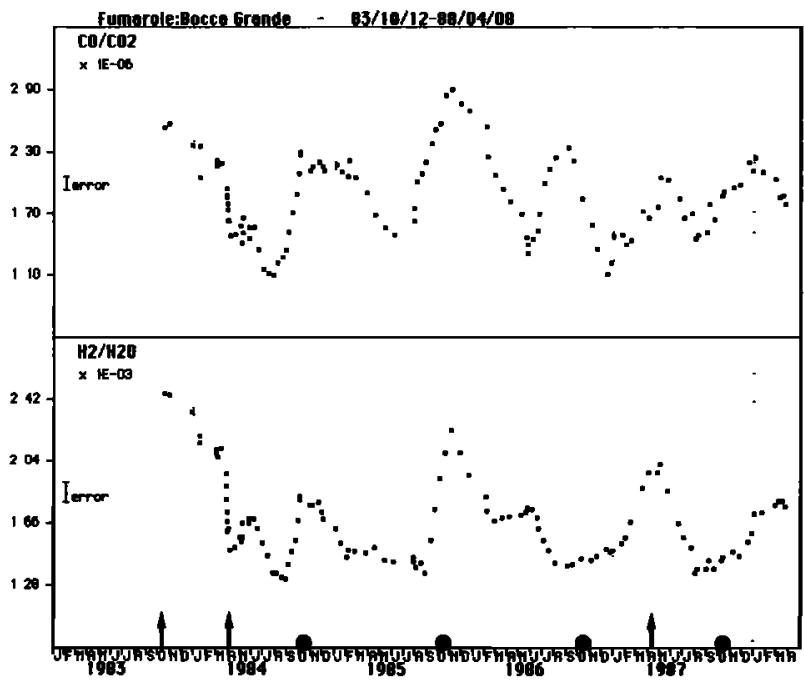

Figure 4. The $\mathrm{CO} / \mathrm{CO}_{2}$ and $\mathrm{H}_{2} / \mathrm{H}_{2} \mathrm{O}$ ratios show large seasonal variations, due mostly to the different solubilities of the four chemical species; higher for $\mathrm{CO}_{2}$ and $\mathrm{H}_{2} \mathrm{O}$ compared to $\mathrm{CO}$ and $\mathrm{H}_{2}$. This means that the $\mathrm{CO}_{2}$ and the $\mathrm{H}_{2} \mathrm{O}$ will remain preferentially in the liquid phase in the superficial geothermal reservoir, when cold water from rainfall is added to it (Autumn-winter period).

table situated at about 400 meters below the crater in agreement with geophysical data (Ortiz et al., 1984; Tedesco, 1987). The temperature difference between this water table and the fumaroles (whose outlet temperature is $155^{\circ}-160^{\circ} \mathrm{C}$ ) corresponds roughly to the temperature decrease for isoenthalpic expansion of water vapour in a porous medium. The variations of the calculated temperature $T_{c}$ during five years (if we exclude seasonal variations), indicate that only slight changes occurred in the equilibrium temperature at depth, as evidenced from the almost uniform value of the $\mathrm{P}(\mathrm{CO}) / \mathrm{P}\left(\mathrm{CO}_{2}\right)$ and $\mathrm{P}\left(\mathrm{H}_{2} / \mathrm{H}_{2} \mathrm{O}\right)$ ratios; in fact both ratios show, at the same time, oscillations of the same order of magnitude, but this is not reflected in the calculated equilibrium temperature $T_{c}$ (figure 5 ), because one oscillation neutralises the other. The only change that could have occurred during this time is a variation of the superficial thermal regime, as indicated by a decrease of $\mathrm{H}_{2} \mathrm{O}$ content. In our opinion the $\mathrm{P}(\mathrm{CO}) / \mathrm{P}\left(\mathrm{CO}_{2}\right)$ ratio can be considered as the most relevant parameter to detect any change in thermal regime at the Solfatara. Indeed, this ratio varies from $10^{-6}$ in a geothermal system (for example, the value of this ratio in the fumaroles of the Solfatara is $2 * 10^{-6}$ and gives up to $10^{-1}$ in a magmatic system (e.g. the lava lake of Erta Ale), [Alland et al., 1977].

Consequently a particular effort should be made to analyse carbon monoxide, a too often overlooked trace gas in tables giving the composition of fumarolic gases. It must however be noted that the Fischer-Tropsch geothermometer and the conversion geothermometer yield contradictory results. From the Fischer-Tropsch reaction we can calculate an equilibrium temperature of $160 \pm 15^{\circ} \mathrm{C}$ at $1 \mathrm{~atm}$ total pressure (surface) which is nearly identical to the sampling temperature of $155-160^{\circ} \mathrm{C}$, which did not show any change during the bradyseismic crisis. The difference between the two calculated temperatures (conversion and FischerTropsch reactions) is due to an excess of methane in the fumarole composition. Therefore, this coincidence between the calculated $\mathrm{T}_{\text {F.T. }}$ and the outlet temperature suggests that a very superficial re-equilibration of methane concentration takes place just before sampling, although an organic contamination is generally inferred by other authors [Matsuo, 1961; Carapezza et al. 1984] for the excess of methane. The equilibrium temperature $T_{F . T}$ constantly increases from 1984 to early 1986 and keeps rather constant level until today (Fig. 5)

\section{Conclusion}

The inflow of hot gases, if any, from a hypothetical magmatic reservoir situated at a depth of about 4-5 $\mathrm{Km}$ (the maximum foci of earthquakes recorded at Campi Flegrei) [De Natale et al., 1984] is not reflected by significant changes in the chemistry of the gas phase. Moreover the ${ }^{3} \mathrm{He} /{ }^{4} \mathrm{He}$ ratio, as measured in 1978 [Poliak and Tolstikhin, 1979], before the bradyseismic crisis took place was $3.8 * 10^{-}$ 6, which can be considered as a typical value for a geothermal system [Hooker et al., 1985] in contrast to the atmospheric ratio of $1.4 * 10^{-6}$. In these same gases, during the maximum stage of the geophysical activity Wakita et al., in 1984 (personal comunication) measured $3.48 * 10^{-6}$.

It seems interesting to us to compare our data and variations in Campi Flegrei fluids to fluids monitored on other active volcanic areas. An example could be the results obtained on Mt. Usu in Japan, where after the 1977 eruption, some authors studied the evolution of the gas phase [Matsuo et al., 1982; Wakita et al., 1985 and Tedesco, 1987]. The $\mathrm{CO} / \mathrm{CO}_{2}$ ratio decreases from $1.82 * 10^{-5}(1979)$ to $0.16 * 10^{-6}$ (1985), the ${ }^{3} \mathrm{He} / 4 \mathrm{He}$ ratio from $9.6 * 10^{-6}$ to $6.9 * 10^{-6}$ and the calculated equilibrium temperature from $500^{\circ}-700^{\circ} \mathrm{C}$ (1979. 80 ) to $300-400^{\circ} \mathrm{C}$ calculated in 1985 . These data explain the slow evolution of fluids from a magmatic to a hydrothermal system.

These values strengthen our conclusion that no new magmatic gas is involved in this crisis and that there have been no significant and detectable injections of deep gases into the Solfatara geothermal system from a magmatic reservoir. In fact our thermodynamical considerations lead us to believe that the recorded concentration variations of the chemical species are due only to a slight change in

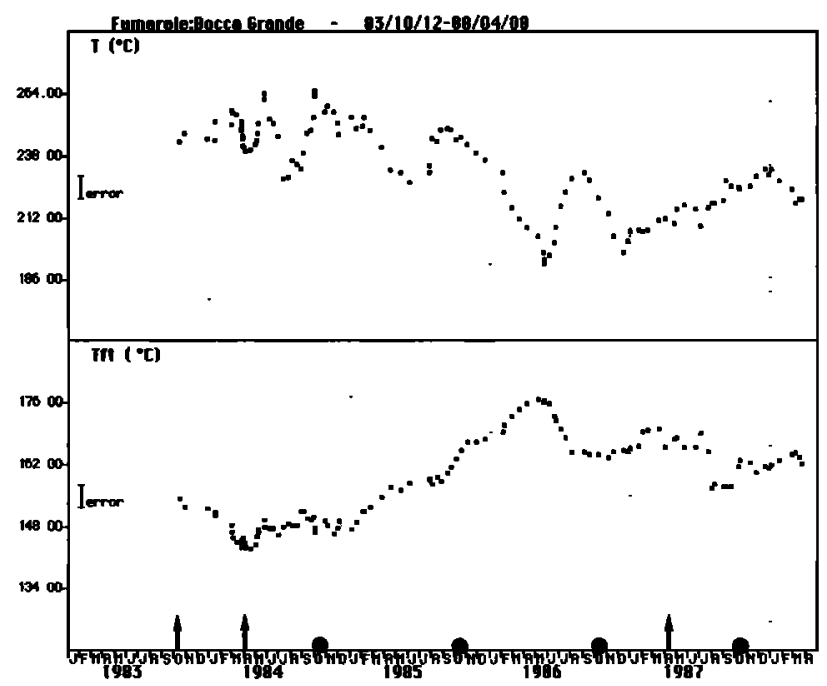

Figure 5. The two calculated equilibrium temperatures $T_{c}$ (conversion or gas-water-shift reaction)) and TF.T. (FisherTropsch reaction) show different trends, due to the behaviour of the two ratios $\mathrm{H}_{2} / \mathrm{H}_{2} \mathrm{O}$ and $\mathrm{CH}_{4} \mathrm{H}_{2}$. in this case when $\mathrm{H}_{2}$ decreases $T_{c}$ will decrease too and $T_{F . T}$. will increase (increase of the $\mathrm{CH}_{4} / \mathrm{H}_{2}$ ratio). All data have been submitted to a moving average (every 5 samples) statistical treatment. 
thermodynamic regime of the geothermal system probably due to the tectonic activity. As a conclusion we believe that the chemical changes in the Solfatara gases noticed by other authors before the crisis were due to an increase in thermal flow (mostly steam from deeper and hotter acquifers into the shallow water table) rather than to an input of gases from deeper origin. In this context, the recorded temporal change in the equilibrium temperature of Bocca Grande fumarole could be a useful signal to follow the volcanic activity of this hydrothermal system.

Acknowledgements. This work has been supported by the Ossevatorio Vesuviano and the C.F.R. (CEA-CNRS). This is a Centre des Faibles Radioactivités contribution number 978.

\section{References}

Allard P., Le Guern F., Sabroux J.C.: Thermodynamic and isotopic studies of eruptive gases. Geothermics, vol. $5^{\circ}$, n 1-4: 37-40 (1977).

Barberi F., Corrado G., Innocenti F., Luongo G.: Brief chronicle of a volcano emergency in a densely populated area. Bull. Volcanol. 47, 175-185 (1984).

Barin I., Knacke O., Kubaschewsky O.: Thermochemical properties of inorganic substances. Springer-Verlag, Berlin 921p (1977).

Berrino G., Corrado G., Luongo G., Toro B.: Ground deformation and gravity changes accompanying the 1982 Pozzuoli uplift. Bull. Volcanol.47, 187-200 (1984).

Berrino G., Corrado G., Luongo G.: Rapporto Osservatorio Vesuviano (1986).

Carapezza M., Nuccio P. M. and Valenza M.: Geochemical surveillance of the Solfatara of Pozzuoli (Phlegrean Fields) during 1983. Bull. Volcanol, 41: 303-311 (1984).

Cioni R., Corazza E., Magro G.: Gases at Solfatara (Italy) surveillance implications. Abstract in Proceedingsof $18^{\text {th }}$ IAVCEI, Hamburg (1983).

Cioni R., Corazza E., Marini L.: The gas/steam ratio as indicator of heat transfer at the Solfatara fumaroles, Phlegraean Fields (Italy). Bull. Volcanol 47: 295-302 (1984).

De Natale G., Zollo A., Del Gaudio C., Ricciardi G., Martini M.: Error analysis in hypocentral locations at Phlegraean Fields, South-central Italy. Bull. Volcanol. 47: 209-218 (1984).

Giggenbach W.: A simple method for collection and analysis of volcanic gases. Bull. Volcanol. 39: 132-145 (1975).
Hooker P.J., Beltrami R., Lombardi S., O'Nions K., Oxburgh E.R.: Helium-3 anomaly and crustal mantle interaction in Italy. Geoch. et Cosmoch. Acta vol 49: 25052513 (1986).

Irvine T.F., Hartnett J.P.: Steam and air tables in SI units. McGraw-Hill (1976).

Lirer L., Luongo G., Scandone R.: On the volcanological evolution of Campi Flegrei. EOS, vol. 68, no. 16, pp 226-231, April 21, (1987).

Martini M.: Thermal activity and ground deformations at Phlagraean Fields, Italy: Precursors of eruptions or fluactuations of quiescent volcanism? A contribution of geochemical study. J. Geoph._Res. 91, B12: 12.255 (1986).

Matsuo S.: On the chemical nature of fumarolic gases of volcano Showa-shinzan, Hokkaido, Japan. J. Earth Sci. Nagova Univ. 80-100 (1961).

Matsuo S, Ossaka J., Hirabayashi J., Ozawa T. e Kimishima S.: Chemical nature of volcanic gases of Usu volcano in Japan. Bull. Volcanol, 45: 261-264, (1982).

Ortiz R., Arana V., Astiz M., Valentin A.: Magnetotelluric survey in the bradeyseismic area of Phlegraean Fields. Bull. Volcanol. 47, 239-246 (1984).

Poliak B.G., Tolstikin, I.N.: Geotectonics, heat flux and helium isotopes: tripple relationship. Intern. Symp. KAPG 1-4, Leningrad, Oct 1980, Acad. Sci. URSS: 51pp (1979).

Tedesco D., Sabroux J.C.: Determination of deep temperatures by means of the $\mathrm{CO}-\mathrm{CO}_{2}-\mathrm{H}_{2}-\mathrm{H}_{2} \mathrm{O}$ geothermometer: an example using fumaroles in the Campi Flegrei, (Italy). Bull. of Volcanol. vol.49. 381387.

Tedesco D.: Significato ed elaborazione termodinamica dei fluidi di ambienti geotermici (Campi Flegrei, Long Valley) e vulcanici (Hawaii, Usu), thesis. University of Naples, 1987.

Wakita H., Sano Y. e Nakamura Y.: ${ }^{3} \mathrm{He} /{ }^{4} \mathrm{He}$ ratios at Mount Usu, Japan. $2^{\text {nd }}$ Workshop on volcanic gases. Matso editor.

D. Tedesco and J. C. Sabroux, Centre des Faibles Radioactivités, 91198 Gif sur Yvette, France.

D. Tedesco, Osservatorio Vesuviano, Via Manzoni 249, 80123 Napoli, Italia.

R. Pece, Dipartimento di Geofisica e Vulcanologia, Largo S. Marcellino, 80138 Napoli, Italia.

(Received May 27, 1988 accepted July 27, 1988) 